\title{
LANGUAGE OF FAMILY COMMUNICATION IN THE MODERN TATAR-RUSSIAN BILINGVAL SOCIETY
}

\author{
Gulshat R. Galiullina ${ }^{1}$ \\ Enze Kh. Kadirova ${ }^{2}$ \\ Gulfiya K. Khadieva ${ }^{3}$ \\ Khalisa Kh. Kuzmina ${ }^{4}$ \\ Zilya M. Kajumova ${ }^{5}$
}

\begin{abstract}
The article is devoted to the study of the functional potential and specificity of use of native language in family communication, in the conditions of modern Tatar-Russian bilingualism. The sociolinguistic study was conducted on the basis of a survey of humanities students, taking into account the type of family, place of residence and language of instruction at school. The choice of respondents of this category is explained by the fact, that they are sufficiently dynamic and receptive to new sociocultural and political conditions. They were brought up in the conditions of intensification of bilingualism development on the one hand, and the
\end{abstract}

\footnotetext{
${ }^{1}$ Kazan Federal University.enge@inbox.ru.

${ }^{2}$ Kazan Federal University.enge@inbox.ru.

${ }^{3}$ Kazan Federal University.enge@inbox.ru.

${ }^{4}$ Kazan Federal University.enge@inbox.ru.

${ }^{5}$ Kazan Federal University. enge@inbox.ru.
}

activation of national identity on the other. The analysis shows, that in the modern active bilingual society the language of family communication has its own specificity and vary, depending on the place of residence and the type of family. The rural family, predominantly, uses its native language in domestic communication. In a rural family, children speak their mother tongue with their parents and brothers and sisters. The urban family, living in the environment of Russian-Tatar bilingualism, prefers to use both languages. Outside the family society, respondents actively use Russian language. The survey shows, that the 
degree of functioning of native language in urban families between children and their parents is higher, than between close relatives. The penetration of bilingualism into the family environment is also observed in modern families, implementing Tatar-Russian bilingualism. Native Tatar language is the first for the members of such families.

Keywords: bilingualism, sociolinguistics, family, language of family communication, Tatar language.

\section{Introduction}

The family is the environment where social and economic processes take place; cultural and behavioural stereotypes are built. Since the sphere of family communication is an important context for the functioning of the first language of the child, and later it becomes a significant part of communication space of language personality, the study of language of family communication is of great interest.

The language of family society can reflect all the elements of native language: colloquial and literary forms, the elements of social and territorial dialects. Language in family communication can reflect mutual influence and interaction, combination of different languages at the level of spoken language. Despite the widespread belief that in small communities the probability of linguistic homogeneity is high, modern families speak not only one language - the mother tongue. In family communication two languages are used. This phenomenon is most common in bi-and multi-lingual society.

In modern linguistics, the study of language of family communication, in the conditions of close contact between different linguistic cultures, is conducted mainly among migrant families, and the language of family society, which exists in the conditions of prolonged contact of different languages and cultures, remains outside of proper attention.

Meanwhile, bilingual society forms a special environment, where the interaction of languages occurs at all levels of communication. In this respect, Tatar-Russian bilingualism, whose roots go deep into history, is of great interest. The main aspects of this issue are 


\section{Periódico do Núcleo de Estudos e Pesquisas sobre Gênero e Direito Centro de Ciências Jurídicas - Universidade Federal da Paraíba V. 8 - No 04 - Ano 2019 - Special Edition ISSN | 2179-7137 | http://periodicos.ufpb.br/ojs2/index.php/ged/index}

reflected in the work of such researchers as L.K. Bayramova [1], O.P. Esin [2], F.F. Kharisov [3], A.M. Ismagilova [4], O.A. Maximova [5], L.R. Nizamova [6], M.I. Solnyshkina [7], R.R. Zamaletdinov [8] and others.

Despite the existing works on Tatar-Russian bilingualism, the peculiarities of language functioning in the family are not often researched. For example, the problems of language of family communication in the conditions of Tatar-Russian bilingualism were studied by such researchers as G.R. Galiullina [9], Z.A. Iskhakova [10], T.A. Titova [11] and others.

The purpose of this article is to identify the functional potential and the specificity of use of native language in family communication, in the conditions of modern Tatar-Russian bilingualism. Given that the functioning of language among young generation is one of the indicators of language vitality, the study was conducted among this category of respondents.

\section{Methods}

In the process of research, a set of methods and techniques was used, which allowed to come to the main results. With the help of descriptive method, scientific-theoretical and empirical materials were studied, language phenomena were described.

The main method of research is the questionnaire survey, as the method of sociolinguistic analysis. The survey involved 220 humanities students, which were the residents of the Republic of Tatarstan, at the age of 17-23. This category of respondents is quite dynamic, susceptible to new social, political and cultural conditions. It was brought up in the conditions of intensification of bilingualism development on the one hand, and the activation of national consciousness on the other hand. Among them 173 respondents $(78.6 \%)$ are Tatars, 32 respondents (14.6\%) are Russian, and 15 $(6.8 \%)$ are the representatives of other nationalities. Two-thirds of the respondents use Tatar language as the first, and implement Tatar-Russian bilingualism.

The questionnaire contained questions, which were focused on identifying the language competence of respondents, and the functional potential 
of native language in family society. As the survey results show, $93.2 \%$ of respondents were brought up in a monoethnic family, and $8.6 \%$ - in an interethnic family.

$59 \%$ of all respondents were brought up in rural families, $40.9 \%$ - in urban families. The parameters of Tatars-respondents are as follows: $67.6 \%$ - are the representatives of rural family, $32.4 \%$ - are the representatives of urban family. Differentiation by the place of residence was necessary for establishing the specifics of realization of Tatar language functions as mother tongue by urban and rural respondents.

Half of the respondents received education in general education establishments with Tatar language of teaching, the second half of respondents - with Russian language of teaching.

Correlation analysis was also used for processing the data obtained. It allowed to establish a correlation between the language situation, competence and social parameters of the respondents.

\section{Results and discussion}

Tatar-Russian bilingualism has developed over the centuries. Close contacts and living in the neighbourhood of the Tatar and Russian population on the territory of the modern Republic of Tatarstan contributed to the formation and development of bilingualism. In addition, the Volga region and the Southern Cisurals were historically a place of close contact with other ethnic groups and their cultures. By the end of the twentieth century, in the conditions of multi-ethnic society, the intensification of migration processes, the expansion of cultural contacts, and the prevailing socio-political situation, active bilingualism embraced all social and age groups of the population. Despite such socio-demographic and linguistic characteristics as the place of birth, the language of teaching at school, the type of family, modern Tatar youth is fluent in Russian. For example, the answers to the question "How fluently do you speak Russian?" are as follows: $87.2 \%$ of respondents speak perfect Russian, read and write; $5.1 \%$ - speak fluently, but read and write with difficulties; $7.7 \%$ - speak with difficulties. 
The answers of Tatar respondents to the question "How fluently do you speak Tatar?" are the following: the overwhelming majority of respondents from rural families $(94 \%)$ speak perfect Tatar, read and write; $3.4 \%$ - speak fluently, but read and write with difficulties; $2.6 \%$ - speak with difficulties.

$65.5 \%$ of Tatar respondents, who were brought up in urban families, fluently speak, read and write in their native Tatar language. $21.9 \%$ of respondents speak fluently, but read and write with difficulties; $5.5 \%$ of respondents speak with difficulties; $5.5 \%$ - understand, but don't speak, $1.6 \%$ - do not speak Tatar language.

The significance and future of language depends on the degree of knowledge of native language by the young generation. According to our sociological survey, the majority of Tatar respondents recognize Tatar as the native language $(95.5 \%)$. Russian language is native to $4.05 \%$ of Tatar respondents. And as the first language, $90 \%$ of Tatar respondents choose Tatar, and $9.2 \%$ of respondents choose Russian. As we see, the respondents have some differences in the recognition of native language and the first language. It is, probably, due to the understanding of native language as a language of ethnicity.

Among Russian respondents, 96.9\% recognize Russian as the native language; $3.1 \%$ of respondents identify themselves as Russian (mother - Tatar, father - baptized Tatar), but they choose Tatar language as native.

The sphere of family communication is the environment of everyday contact in family, the importance of which is conditioned by the fact that, as a rule, the acquisition of mother tongue takes place in the family, in communication with parents. It belongs to the number of amorphous communicative spheres, which are not regulated [12: 223]. Constant communication in native language in family society promotes the development of language personality, the transmission of ethno-cultural and family traditions between generations. In addition, the language of family communication demonstrates the potential of language, the possible ways of development and enrichment of its entire system, change in the volume of 


\section{Periódico do Núcleo de Estudos e Pesquisas sobre Gênero e Direito Centro de Ciências Jurídicas - Universidade Federal da Paraíba V. 8 - $\mathrm{N}^{\circ} 04$ - Ano 2019 - Special Edition ISSN | 2179-7137 | http://periodicos.ufpb.br/ojs2/index.php/ged/index}

words meanings, the spheres of their use, the specifics of perception and acquisition of linguistic units, the creation of new words and meanings, etc. If the native language functions only within this microsociety, without going beyond, it remains flawed, and it will not be able to realize all the functional potential. In our study, we focused on this problem and conducted comparative analysis of the responses of Tatar respondents (see Table 1).

Table № 1:Language of respondents - Tatars inside and outside the family, \%

\begin{tabular}{|l|l|l|l|l|}
\hline Settlement & Language & $\begin{array}{l}\text { With } \\
\text { parents }\end{array}$ & $\begin{array}{l}\text { With brothers } \\
\text { and sisters }\end{array}$ & $\begin{array}{l}\text { With } \\
\text { friends }\end{array}$ \\
\hline City & Only in the native & 23.2 & 19.6 & 1.8 \\
\cline { 2 - 6 } & Mainly in the native & 25 & 17.9 & 7.3 \\
\cline { 2 - 6 } & $\begin{array}{l}\text { To the same extent in } \\
\text { native and Russian }\end{array}$ & 32.1 & 37.5 & 43.6 \\
\cline { 2 - 6 } & Basically in Russian & 14.3 & 14.3 & 34.6 \\
\cline { 2 - 6 } & Only in Russian & 5.4 & 10.7 & 12.7 \\
\hline Village & Only in the native & 71.8 & 60.7 & 44.5 \\
\cline { 2 - 6 } & Mainly in the native & 19.7 & 25.6 & 31.9 \\
\cline { 2 - 6 } & To the same extent in & 6.7 & 8.6 & 7.8 \\
\hline & native and Russian & & 3.4 & 0 \\
\cline { 2 - 6 } & Basically in Russian & 0.9 & 1.7 & \\
\cline { 2 - 5 } & Only in Russian & 0.9 & & \\
\hline
\end{tabular}

As the results of the research show, in urban families, communication is made in the native and Russian languages to the same extent. This is observed in communication as with parents $(32.1 \%)$, as with close relatives $(37.5 \%)$. The degree of functioning of native language in urban families between children and their parents is higher, than between close relatives. As we see, in the communication of children among themselves, there is a decrease in the activity of native language in favour of Russian language in all indicators. So, 


\section{Periódico do Núcleo de Estudos e Pesquisas sobre Gênero e Direito Centro de Ciências Jurídicas - Universidade Federal da Paraíba V. 8 - No 04 - Ano 2019 - Special Edition ISSN | 2179-7137 | http://periodicos.ufpb.br/ojs2/index.php/ged/index}

for example, $23.2 \%$ of respondents from urban families speak with their parents in their mother tongue, and only $19.6 \%$ of the respondents communicate with their brothers and sisters in their native language. Outside the family there is a sharp decline in the activity of native language functioning. For example, only $1.8 \%$ of respondents communicate with their friends in their native language. Outside the family, the young generation communicates in native and Russian languages to the same extent $(43.6 \%)$, or mostly in Russian (34.6\%).

The active functioning of bilingualism, first of all, is observed in the urban environment, where Russian is the dominant language. It covers all spheres of communication, including the family society. It should be noted, that the intensive development of bilingualism has a strong influence on the language of family communication of rural population, which manifests itself in the form of mixed speech.

It is well known, that ethnocultural traditions in a rural family, unlike urban families, are preserved better and are handed down consistently. They are less susceptible to influences from the outside, and are characterized by stability and conservatism. The study of the rural family makes it possible to understand fully the depth and scale of the spread of bilingualism in modern society. For this reason, we paid special attention to the language of family communication in rural areas. As can be seen from Table 1, in a rural family, $71.8 \%$ of children communicate with parents only in Tatar language, and with brothers and sisters $-60.7 \%$. The values of the variant "Mainly in the native" are lower in the family society, and the percentage of respondents, who communicate outside the family mainly in the native language, differs markedly $(44.8 \%)$.

The use of the second (Russian) language instead of the native is especially noticeable in small towns and villages, where the language of instruction is Russian. However, as our analysis shows, Russian language, as the language of family communication, gradually penetrates into the rural family, not only as a mixed speech, but also as a language of family communication. 
Summary

Thus, in a modern active bilingual society, the language of family communication is complex and differs depending on the place of residence and the type of family. Traditional rural family (the carrier of Tatar-Russian bilingualism) actively uses native language in its domestic communication, and the urban family, living in the environment of Russian-Tatar bilingualism, prefers to use both languages. In such environment, the young generation actively uses Russian language in communication outside the family society.

\section{Conclusions}

As the research shows, in modern conditions, Tatar-Russian bilingualism actively develops and penetrates into such a stable sphere as family society. This phenomenon is also observed in modern families, implementing TatarRussian bilingualism. Native Tatar language is the first for the members of such families.

\section{Acknowledgements}

The work is performed according to the Russian Government Program of Competitive Growth of Kazan Federal University. Funded by Volkswagen Foundation (AZ № 90217, 2016-2019).

\section{Bibliography}

Bayramova L.K. Tatarstan: language symmetry and asymmetry. - Kazan: Publishing House of Kazan University, 2001. - 267 p.

Esin O., Gorobets E., Galiullin K., Kulsharipova R. The Description of Pain by Bilingual Patients with Neurological Disorders: a Linguistic Study // SGEM Conference on Psychology \& Psychiatry, Sociology \& Healthcare, Education: Conference Proceedings (Bulgaria, International Multidisciplinary Scientific Conferences on Social Sciences and Arts, 3-9 September 2014). - 2014. - V.1. - Pp. 449-456.

Shakirova G.R., Kharisova C.M., Kharisov F.F. Methodical Support of Teaching of Parts of Speech in Teaching of the Native Language // Modern 
Journal of Language Teaching Methods. Special Issue (December 2016). - 2016, Vol., ISSN: 2251-6204. - Pp.155-160.

Ismagilova A.M., Galiullina G.R., Kuzmina Kh. Kh. Functional potential of mother tongue in conditions of bilingualism among youth of the Republic of Tatarstan // Modern Journal of Language Teaching Methods. Special Issue (December 2016). - Pp. 66-70.

Maximova O., Belyaev V., LaukartGorbacheva O. Transformation of the system of bilingual education in the Republic of Tatarstan: Crossover ethnolinguistic controversies // Journal of Social Studies Education Research. 2017. - Vol.8, Is.2. - Pp.15-38.

Nizamova L. Ethnic Tatars in Contention for Recognition and Autonomy: Bilingualism and Pluri-Cultural Education Policies in Tatarstan, in Nationalities Papers. The Journal of Nationalism and Ethnicity. 2016. Vol. 44. №1. Pp. 71-91.

Solnyshkina M.I., Ismagilova A.R. (2015). Linguistic landscape westernization and globalization: The case of Kazan, Republic of Tatarstan. XLinguae, 8(2), 36-53.

Zamaletdinov R.R., Yusupov F.Y., Karabulatova I.S., Yusupov A.F., Husnutdinov D.H. The formation of Tatars ethnic groups in the Southern Urals and Trans Urals region // Life Science Journal, 2014. - № 11(11S). Pp. 214-217.

Galiullina G.R., Ildarkhanova F.A. Ethnocultural values of modern families of the Republic of Tatarstan // Bulletin of Kazan Technological University. - 2012. - Vol.15, №1. - Pp. 203-207.

Iskhakova Z.A. Ethno-linguistic issues in modern inter-ethnic families of Tatarstan / TATARICA. - 2015. №2 (5). - Pp. 7-14.

Titova T.A. Ethnic minorities in Tatarstan: status, identity, culture. Kazan: KSU, 2007. - 254 p.

Dictionary of sociolinguistic terms / V.A. Kozhemyakina, N.G. Kolesnik, T.B. Kryuchkova and others; executive 
Periódico do Núcleo de Estudos e Pesquisas sobre Gênero e Direito Centro de Ciências Jurídicas - Universidade Federal da Paraíba V. 8 - No 04 - Ano 2019 - Special Edition ISSN | 2179-7137 | http://periodicos.ufpb.br/ojs2/index.php/ged/index

editor V.Yu. Mikhalchenko. The

Institute of Linguistics, Russian

Academy of Sciences. - Moscow: 2006.

$-312 p$ 